Creative Commons User License: CC BY-NC-ND

Abstracted by: EBSCOhost, Electronic Journals Service (EJS),

Google Scholar, Journal Seek, Scientific Commons,

Food and Agricultural Organization (FAO), CABI and Scopus

http://eoi.citefactor.org/10.11226/v25i4
Journal of Agricultural Extension

Vol. 25 (4) October, 2021

ISSN(e): 24086851; ISSN(Print); 1119944X

http://journal.aesonnigeria.org

http://www.ajol.info/index.php/jae

Email: editorinchief@aesonnigeria.org

\title{
Digitization of Agricultural Extension System for Effective Management of Emergency in Nigeria
}

https://dx.doi.org/10.4314/jae.v25i4.9

\section{Olagunju, Oluwatoyin}

Department of Agricultural Extension and Rural Development, Faculty of Agriculture, Adekunle Ajasin University, Akungba-Akoko, Nigeria. Email: toyinolagunju01@gmail.com; Phone: +2348032053139

\section{Adetarami, Oluwaseun}

Department of Agricultural Extension and Rural Development, College of Agricultural Management and Rural Development, Federal University of Agriculture, Abeokuta, Nigeria. Email: adetaramio@funaab.edu.ng; Phone: +2348030786885

\section{Koledoye, Gbenga Festus}

Department of Agricultural Extension and Rural Development, Faculty of Agriculture, Adekunle Ajasin University, Akungba-Akoko, Nigeria. Email: gbengakoledoye@gmail.com; Phone: +2348035603497

\section{Olumoyegun, Adewumi Temidire}

Department of Agricultural Extension and Rural Development, Faculty of Agriculture, Adekunle Ajasin University, Akungba-Akoko, Nigeria. Email: temidirepoint1@gmail.com; Phone: +2348039253180

\section{Nabara, Isah Shehu}

Department of Agricultural science education, Niger State College of Education, Minna, Nigeria. Email: nabaraisah@gmail.com; Phone: +2348035958943

\section{Abstract}

This paper presents challenges facing agricultural extension system in Nigeria most especially, during crises and emergencies, which necessitate the adoption of digitizing extension systems as a basis for improving farmers' access to extension services during emergencies. The emergence of ICTs has given rise to digitization, which is the delivery of agricultural advice via audiovisual messages (video), interactive voice response (IVR) and short message services (SMS) among others. Efforts should be made by the stakeholders in agricultural extension to digitize the country's extension system by capitalizing on the existing enthusiasm among extension practitioners, and farmers using lessons of best practices from elsewhere.

Keywords: Agricultural extension, digitization, emergency, management of extension 
Creative Commons User License: CC BY-NC-ND

Abstracted by: EBSCOhost, Electronic Journals Service (EJS), Google Scholar, Journal Seek, Scientific Commons,

Food and Agricultural Organization (FAO), CABI and Scopus

http://eoi.citefactor.org/10.11226/v25i4
Journal of Agricultural Extension

Vol. 25 (4) October, 2021

ISSN(e): 24086851; ISSN(Print); 1119944X

http://journal.aesonnigeria.org

http://www.ajol.info/index.php/jae

Email: editorinchief@aesonnigeria.org

\section{Introduction}

Agricultural extension programmes have been offered since colonial times to help deliver essential knowledge, including agricultural technology to farmers and rural dwellers in both developed and developing countries (Danso-Abbeam, Ehiakpor, and Aidoo 2018). Interestingly, Aker, Ghosh and Burrell (2016) recorded more than 140 digital agricultural initiatives globally in their review of the promises and setbacks found in the use of ICT in agricultural work. Digital technologies have enabled farmers to become more motivated on the market by linking them to people who can buy or sell their produce, and also by promoting their use of digital financial services, such as loans, to expand their farms (Aker et al., 2016). Several of these initiatives are made possible in various areas of agricultural extension service by mobile phones using landline, computers, and web-based technologies (Onubedo, Bodunrin, and Ishaku 2018 and Aker et al., 2016).

Digital agricultural extension is a scalable, cost-effective solution that allows farmers access to actionable knowledge (Kurdyś-Kujawska et al, 2021). Even when there is an in-person extension, interactive platforms are a significant addition to conventional extension services. When conventional in-person communication networks are impossible in an emergency setting, investing in low-cost digital tools to provide farmers with information and market connections they need, gathering realtime information on the challenges on the ground, and adapting these tools to tackle new challenges are becoming urgent priorities. Digital agricultural extension is now helping millions of farmers around the world gain access from the palm of their hand to the best agricultural knowledge and advice.

Also, considering the opportunities made available to people working in the agricultural sector through digital technology, the adoption of ICT by farmers and those employed in the agricultural sector is far from universal (Saiz-Rubio \& RoviraMás, 2020). The explanations for this are complicated, but many are related to the conditions in which the agricultural workforce operates, such as the lack of connectivity and the nature of the technologies implemented to support their work. A significant obstacle to the adoption of ICT by agricultural workers and farmers is simply that they are unaware that such digital solutions exist (Anyan \& Frempong 2018).

In this age of digital technology, not only extension staff but also farmers are naturally attracting interest and attention in the use of ICT in the agricultural sector. That is because ICTs are now being used in different ways for social interaction. However, farmers need to be well trained and equipped with the advantages hidden in ICTs that can be used to keep them informed about a set of threats and emergencies such as weather fluctuations, natural disasters, price uncertainties, personal risks, abrupt institutional and policy changes that strongly influence decisions on input use, investment and technology adoption (Muhammad et al., 2018). 
Creative Commons User License: CC BY-NC-ND

Abstracted by: EBSCOhost, Electronic Journals Service (EJS), Google Scholar, Journal Seek, Scientific Commons,

Food and Agricultural Organization (FAO), CABI and Scopus
Journal of Agricultural Extension

Vol. 25 (4) October, 2021

ISSN(e): 24086851; ISSN(Print); 1119944X

http://journal.aesonnigeria.org

http://www.ajol.info/index.php/jae

Email: editorinchief@aesonnigeria.org

Specifically, different ICTs are attracting the attention of various development sectors in Nigeria as they are convenient, speedy, and resourceful. Conversely, due to a lack of understanding and information about its potential position in managing agricultural risks and emergencies, the digital-based agricultural sector is less focused. Khan et al. (2020) have pointed out that current (traditional) extension methods, such as person, community, and mass communication methods; need to be grafted into ICTs to make knowledge accessible to all players in an effective, fast and efficient manner. Ultimately, it will strengthen the conventional extension system. Tata and McNamara (2018) conducted a study in Kenya, emphasizing the need to integrate ICTs into the agricultural extension system through government-level investments. Notably, failure to adopt ICTs in agricultural extension may lead to underperformance of digital technology for improved extension service delivery, especially in the management of agricultural risk and emergency.

Certainly, the agricultural sector has become riskier as a result of climate change and emergent outbreaks of disease; extension agents are required to help the farming community use ICT for agricultural risk and emergency management (Kumar et al., 2020). This paper discusses the potential for enhanced information-exchange that ICTs can offer through the application of available digital technology for extension services in the management of agricultural risk and emergency among farmers and stakeholders involved in agricultural activities.

The provision of quality agricultural extension services in Nigeria is constrained by an unfavourable staff-to-farmer extension ratio, a poor link between research and extension-farmers, a limited budget, lack of motivation towards extension personnel makes the extension service ineffective, insufficient aids needed to disseminate information, poor transportation networks and logistics, large area of coverage and lack of implementation of agricultural extension policy (Apantaku et al. 2016). It can be inferred from these difficulties that, over the years, the net result has been the failure of the extension service to reach its intended clientele effectively. Excessive, if not complete, reliance on traditional face-to-face extension strategies for interacting and exchanging agricultural information and expertise with clients has further exaggerated the situation. The time has come for the adoption of more innovative ways of reaching out to clientele in an efficient and cost-effective way.

\section{Potential for Adoption of Digital Technology in Extension System}

According to Maertens et al. (2020), before the COVID-19 crisis, extension services mostly employed the "on the field" approaches, such as demonstration plots, group training, and farm visits, all of which implied in-person interaction. However, COVID19-related physical distancing measures made such approach impossible, thereby necessitated the extension personnel to switch to digital tools for service delivery among farmers (Fatty, 2019). 
Creative Commons User License: CC BY-NC-ND

Abstracted by: EBSCOhost, Electronic Journals Service (EJS), Google Scholar, Journal Seek, Scientific Commons,

Food and Agricultural Organization (FAO), CABI and Scopus
Journal of Agricultural Extension

Vol. 25 (4) October, 2021

ISSN(e): 24086851; ISSN(Print); 1119944X

http://journal.aesonnigeria.org

http://www.ajol.info/index.php/jae

Email: editorinchief@aesonnigeria.org

http://eoi.citefactor.org/10.11226/v25i4

While the pandemic presents many challenges, it also creates opportunities for digital tools to better serve farmers, as well as be adapted to assist public health responses, and prepare for new agricultural needs that arise (FAO, 2020a).

Agriculture digitization offers ways to reduce the negative effects of agri-food supply chains and to help farmers receive the financial support and agricultural inputs they need to grow and sell their produce (FAO, 2020b). Digital innovations also make agriculture more attractive to young people, while productivity increases have also been seen by new collaborative arrangements (Saiz-Rubio \& Rovira-Más 2020). According to Babu (2020), risk and emergencies such as disease outbreaks take a toll on the extension system by directly affecting personnel and farmers functions in the short-term. Such disruptions during the growing season can cut off the flow of information to farmers, resulting in a decrease in crop production, livestock and fish production systems.

In the short term, the role of extension staff is altered as the emphasis shifts from providing training on new technological innovations to gathering and disseminating information on the outbreak of disease and its effects on farmers (Babu, 2020). Collectively, these short-term changes can affect the productivity of agricultural systems and lead to lower food and nutrition security (Savary et al., 2020). When Avian Influenza affected parts of Africa, the extension system had a transfer mode to understanding the knowledge and practices of farmers (Elelu, 2017). During the Nigerian Bird Flu, extension personnel were involved in helping the poultry workers reduce the spread of the disease (Okpukpara, 2016). This is an example of the productive deployment of extension workers in the time of disease outbreak.

Advances in digital technology offer an incentive for developing countries, including Nigeria, to exploit and use information and expertise to boost agriculture (Anyoha et al., 2018). Yousaf et al. (2021) claimed that the rapid spread of digital technologies in developing countries provides a unique opportunity for the transfer of knowledge through private and public information systems. Technological developments are creating increasingly powerful computing devices dynamic virtual network that enables people around the world to interact and exchange knowledge with each other (Ajaegbu et al., 2019).

The deployment of digital technology during an emergency also plays a role in contributing to desperately needed changes to enable and help smallholder farmers to respond to the challenges of food security, market growth, climate change, and outbreak of diseases (Grote et al., 2021). Throughout the developing world, this can be incorporated through radio, SMS, television, film and internet services. Thus, digital technologies are opening up new channels for farmers to document and share experiences with specialists. It is clear that using digital tools by the extension personnel and farmers can enhance the different practices of social work, such as the delivery of services, education, and research, when used thoughtfully and effectively (Ajaegbu et al., 2019). 
Creative Commons User License: CC BY-NC-ND

Abstracted by: EBSCOhost, Electronic Journals Service (EJS), Google Scholar, Journal Seek, Scientific Commons,

Food and Agricultural Organization (FAO), CABI and Scopus
Journal of Agricultural Extension

Vol. 25 (4) October, 2021

ISSN(e): 24086851; ISSN(Print); 1119944X

http://journal.aesonnigeria.org

http://www.ajol.info/index.php/jae

Email: editorinchief@aesonnigeria.org

According to Ferri et al. (2020), as they can significantly increase both person-toperson contacts and their access to information; digital technology will fill the information gap left by public extension during crises and emergencies. This is particularly helpful because most farmers are often poor in terms of resources and there are not enough extension workers to reach out to them. For example, digital tools, such as mobile technologies, may be used to broaden the scope of agricultural extension services by allowing farmers to contact technical agricultural advice hotlines or to access market information, such as market locations and prices (Danso-Abbeam et al., 2018). In developing countries, the growth of technology offers new opportunities to users to connect and access vital information, especially for people and communities located remotely (Cascio \& Montealegre, 2016).

Social media as part of digital technology can provide farmers with incredible resources, including helping them find updates on-farm operations and clarifying their questions about the signs of plant or livestock disease (Naruka et al., 2017).

\section{Success Stories from Other Countries}

Several success stories reflecting the potential for the adoption of digital technology in the delivery of services to farmers can be identified. Examples include: Access Agriculture in Bangladesh, Ghana, Kenya, Malawi, Mali, Tanzania, and Uganda; Grameen Foundation Community Knowledge Worker in Uganda and Ghana; Cojengo in Kenya, Ethiopia, Uganda and Tanzania; Digital Green in Afghanistan, India, Ghana, Ethiopia, Niger, Malaysia and Mozambique; e-Krishok in Bangladesh, Pakistan; Esoko in Kenya, Ghana; Farm Radio International in Tanzania, Burkina Faso, Ethiopia, Ghana, Mali, Uganda; Senekela in Mali; KenCall-mKilimo in Kenya; NAFIS in Kenya; Shamba Shape Up in Kenya, Tanzania, Uganda; Growth Enhancement Support Scheme (e-wallet) in Nigeria.

The Access Agriculture was aimed at enhancing the capacity-building capabilities of several local extension service providers, by helping them produce relevant content. The content is translated into local languages and is adapted to the respective regional requirements (Deborah et al., 2018).

The goal of the Grameen Foundation Community Knowledge Worker initiative in Uganda and Ghana was to reach farmers in remote communities via a network of peer advisors by providing rural farmers with free agricultural information and advice on their smartphones through a content database (including crop information, market prices and inputs) and to procure loans to purchase farm supplies such as fertilizers and seeds (Amadu \& McNamara, 2019).

The Cojengo in Kenya, Ethiopia, Uganda, and Tanzania is a Smartphone-based diagnostic tool used in animal health to improve disease diagnosis, surveillance, and treatment of cattle in sub-Saharan Africa (Beyene et al., 2018). 
Creative Commons User License: CC BY-NC-ND

Abstracted by: EBSCOhost, Electronic Journals Service (EJS),

Google Scholar, Journal Seek, Scientific Commons,

Food and Agricultural Organization (FAO), CABI and Scopus
Journal of Agricultural Extension

Vol. 25 (4) October, 2021

ISSN(e): 24086851; ISSN(Print); 1119944X

http://journal.aesonnigeria.org

http://www.ajol.info/index.php/jae

Email: editorinchief@aesonnigeria.org

In India, the ICT initiative called "Digital Green" was designed as a modern innovation to address food scarcity by using modern technological advancements to uplift impoverished farmers (Tinsley \& Agapitova, 2018).

e-Krishok is an agricultural initiative of Bangladesh Institute of ICT in Development (BIID) using ICTs to reach rural farmers with relevant knowledge through Agricultural Information and Advisory (Extension) and Market Linkage Services that provides extension and market linkage services to the smallholder farmers which led to Digital Bangladesh (Rashid \& Islam, 2016).

A team of local and international professionals in Ghana introduced ICT interactive programmes called "Esoko" which is a technology platform that integrates smallholder farmers into the formal value chain by leveraging mobile phone technology in Ghana and Kenya (Ao et al., 2017).

Farm Radio International is an initiative of a Canadian non-governmental organization targeted towards small-scale farmers and rural communities in Africa by leveraging on radio broadcasters. They use radio, a tool that is easily accessed in sub-Saharan Africa, to communicate information on low-cost and sustainable farming practices (Hudson et al., 2017).

In Mali, the ICT initiative called "Senekela Orange" is a service established in Mali that provides farmers' access to updated agricultural advice such as stock availability, product market prices, and weather predictions via mobile phone (Senekela, 2018).

The Kenyan NAFIS, Shamba Shape Up and Kencall are a mobile application which provides information to farmers in Kenya. They are comprehensive information service, intended to serve the needs of smallholder farmers in Kenya including the rural areas where internet access is limited (Kapuscinski, 2017).

In 2012, the Federal Government of Nigeria (FGN) through the Federal Ministry of Agriculture and Rural Development established a new fertilizer distribution scheme called E-wallet system under the Growth Enhancement Support Scheme (GESS) to provide information about where and how to buy fertilizer and the exact amount sold, which allows farmers to compare prices (Godson-lbeji et al., 2016; Demenongu et al., 2018).

\section{Implications for Nigeria}

Examples of success from different countries give Nigeria valuable lessons and prove that digital technology can leverage the power of social media for the advantage of farming communities (Gonte, 2018). The integration of digital technology will play a very important role in bridging knowledge gaps, suggesting that a significant number of farmers can be reached even with very few extension staff. Social networking is a modern medium for sharing ideas; communicating with, contributing to, and mobilizing for a cause; finding advice, and providing guidance. 
Creative Commons User License: CC BY-NC-ND

Abstracted by: EBSCOhost, Electronic Journals Service (EJS), Google Scholar, Journal Seek, Scientific Commons,

Food and Agricultural Organization (FAO), CABI and Scopus
Journal of Agricultural Extension

Vol. 25 (4) October, 2021

ISSN(e): 24086851; ISSN(Print); 1119944X

http://journal.aesonnigeria.org

http://www.ajol.info/index.php/jae

Email: editorinchief@aesonnigeria.org

Social media have eliminated communication hurdles and built decentralized channels of communication and opened the door for everybody to have a voice and engage in a democratic manner (Thakur \& Chander, 2018).

A recently completed study by Emeana et al. (2020) revealed that great potential does exist for the adoption of digital technology in Nigeria. The study established that agricultural extension professionals in the country see the potential for utilization of digital tools to transform them from mere agents of extension into knowledge workers, engaged in bottom-up, demand-driven, pluralistic approaches to technology generation, assessment, refinement, and transfer. The ICT deployment for agriculture extension services was embraced with testimonies of success in the areas of delivery cost-effectiveness, easy and timely access as well as undiluted information to farmers (Hamisu et al., 2017). They possess some level of digital literacy and skills in the use of ICT that needs training and retraining at various levels (farmers, extension agents, researchers, and government ministry staff) to enable them to use such expertise in the management of disease outbreak and every form of emergencies in agriculture (Phillip \& Ndirpaya, 2020; Ajah \& Chigozie-Okwum, 2019; Mojaki \& Keregero, 2019).

Nigeria's agricultural extension professionals understand the country's ability and use of digital technology and are well placed to welcome its introduction as well as implementation. Therefore, a useful starting point may be to sensitize them to begin using selected ICT applications to electronically distribute extension messages to farmers most especially during emergencies.

\section{Conclusions and Recommendations}

The adoption of digital technology could open up new opportunities in service delivery. There is the need to step up advocacy for the use of ICTs in the delivery of extension services in the country.

\section{References}

Ajaegbu, O. O., Ajaegbu, C., \& Sodeinde, O. A. (2019). Smartphone technological advancement trends: A scheme for knowledge acquisition towards societal development. Information Technology Journal, 18, 1-7.

Ajah, I. A., \& Chigozie-Okwum, C. C. (2019). Prospects of ICT for digital growth and national development in Nigeria. International Multi-Disciplinary Journal, Ethiopia AFRREV, 13(3), 192-203.

Aker, J. C., Ghosh, I, \& Burrell, J. (2016). The promise (and pitfalls) of ICT for agriculture initiatives. Agricultural Economics, 47(1), 35-48.

Amadu, F. O., \& McNamara, P. E. (2019). Performance incentives and information communication technologies in Ugandan agricultural extension service delivery. African Journal of Food, Agriculture, Nutrition and Development, 19(1), 14113-14136. 
Creative Commons User License: CC BY-NC-ND

Abstracted by: EBSCOhost, Electronic Journals Service (EJS), Google Scholar, Journal Seek, Scientific Commons,

Food and Agricultural Organization (FAO), CABI and Scopus

http://eoi.citefactor.org/10.11226/v25i4
Journal of Agricultural Extension

Vol. 25 (4) October, 2021

ISSN(e): 24086851; ISSN(Print); 1119944X

http://journal.aesonnigeria.org

http://www.ajol.info/index.php/jae

Email: editorinchief@aesonnigeria.org

Anyan, F. Y., \& Frempong, G. (2018). An investigation into barriers that hinder the effective use of ICT in farming by small scale farmers in Asuogyaman District, Ghana. International Journal of Humanities Social Sciences and Education (IJHSSE), 5(1), 2332.

Anyoha, N. O., Chikaire, J. U., Godson, I. C. C., Ogueri, E. L., Utazi, C. O. (2018). Information and communication technology roles in improving women farmers access to agricultural/agribusiness services in Orlu Agricultural Zone in Imo state, Nigeria. https://www.researchgate.net/publication/329406958_Information_and_Communicatio n_Technology_Roles_in_Improving_Women_Farmers_Access_to_AgriculturalAgribusi ness_Services_in_Orlu_Agricultural_Zone_of_Imo_State_Nigeria/download.18/03/201 9.

Ao, Y., Li, J., Wang, Y., Liu, C., \& Xu, S. (2017). Farmers' satisfaction of rural Facilities and its influencing indicators: A case study of Sichuan, China. Mathematical Problems in Engineering, 2017, 1-12.

Apantaku, S. O., Aromolaran, A. K., Shobowale, A. A., \& Sijuwola, K. O. (2016). Farmers and extension personnel view of constraints to effective agricultural extension services delivery in Oyo State, Nigeria. Journal of Agricultural Extension, 20(2), 202-214.

Babu, S. C. (2020). What Happens to Extension Institutions during Disease Outbreaks and How to Prevent Institutional Capacity Erosion? https://www.agrilinks.org/post/whathappens-extension-institutions-during-disease-outbreaks-and-what-can-be-doneprevent.

Beyene, T. J., Asfaw, F., Getachew, Y., Tufa, T. B., Collins, I., Beyi, A. F., \& Revie, C. W. (2018). A smartphone-based application improves the accuracy, completeness, and timeliness of cattle disease reporting and surveillance in Ethiopia. Frontiers in veterinary science, 5 (2), 1-10.

Cascio, W. F., \& Montealegre, R. (2016). How technology is changing work and organizations. Annual Review of Organizational Psychology and Organizational Behavior, 3, 349-375.

Danso-Abbeam, G., Ehiakpor, D. S., \& Aidoo, R. (2018). Agricultural extension and its effects on farm productivity and income: insight from Northern Ghana. Agriculture \& Food Security, 7(1), 1-10.

Deborah, A. H., Domingo, S. Z., Hamdache, L. Z., Manchaiah, V., Thammaiah, S., Evans, C., Wong, L. L. N. \& On behalf of the International Collegium of Rehabilitative Audiology and TINnitus Research NETwork (2018). A good practice guide for translating and adapting hearing-related questionnaires for different languages and cultures. International Journal of Audiology, 57(3), 161-175.

Demenongu, T. S., Yahaya, M., \& Jiriko, R. (2018). Assessment of farm inputs distribution under the e-wallet scheme in Benue State, Nigeria. International Journal of Agricultural and Food Research, 6(2), 20-29. 
Creative Commons User License: CC BY-NC-ND

Abstracted by: EBSCOhost, Electronic Journals Service (EJS), Google Scholar, Journal Seek, Scientific Commons,

Food and Agricultural Organization (FAO), CABI and Scopus

http://eoi.citefactor.org/10.11226/v25i4
Journal of Agricultural Extension

Vol. 25 (4) October, 2021

ISSN(e): 24086851; ISSN(Print); 1119944X

http://journal.aesonnigeria.org

http://www.ajol.info/index.php/jae

Email: editorinchief@aesonnigeria.org

Elelu, N. (2017). Epidemiological risk factors of knowledge and preventive practice regarding avian influenza among poultry farmers and live bird traders in Ikorodu, Lagos State, Nigeria. International journal of veterinary science and medicine, 5(1), 47-52.

Emeana, E. M., Trenchard, L., \& Dehnen-Schmutz, K. (2020). The revolution of mobile phone-enabled services for agricultural development (m-Agri Services) in Africa: The challenges for sustainability. Sustainability, 12(2), 1-27.

Food and Agriculture Organization of the United Nations (FAO). (2020a). Enabling agricultural innovation systems to promote appropriate technologies and practices for farmers, rural youth and women during COVID-19. Rome. https://doi.org/10.4060/ca9470en.

Food and Agriculture Organization of the United Nations (FAO). (2020b). The Digitalization of Food and Agriculture, FAO Regional Conference Forasia and the Pacific. http://www.fao.org/3/nc580en/nc580en.pdf.

Fatty, L. K. (2019). Agricultural Extension Services Delivery and Post-Harvest Losses of Horticultural Crop Produce in West Coast Region of the Gambia (Doctoral dissertation).

Fan, S., \& Rue, C. (2020). The role of smallholder farms in a changing world. In The Role of Smallholder Farms in Food and Nutrition Security (pp. 13-28). Springer, Cham.

Ferri, F., Grifoni, P., \& Guzzo, T. (2020). Online learning and emergency remote teaching: Opportunities and challenges in emergency situations. Societies, 10(4), 1-18.

Godson-Ibeji, C. C., Chikaire, J. U., \& Anyaoha, N. O. (2016). Assessing the effects of ewallet scheme in farm inputs distribution to rural farmers in Imo State, Nigeria. E3 Journal of Agricultural Research and Development, 6(2), 034-041.

Gonte, K. D. (2018). Application of social media in advertising fresh fruit and vegetable products in Ahmednagar district. International Journal of Modern Trends in Business Research, 1(5), 16-27.

Grote, U., Fasse, A., Nguyen, T. T., \& Erenstein, O. (2021). Food security and the dynamics of wheat and maize value chains in Africa and Asia. Frontiers in Sustainable Food Systems, 4, 1-17.

Hamisu, S., Ardo, A. M., Makinta, M. M., Garba, L., \& Musa, G. (2017). A review on current status of Agricultural Extension Service in Nigeria. Asian Journal of Advances in Agricultural Research, 1(3), 1-8.

Hudson, H. E., Leclair, M., Pelletier, B., \& Sullivan, B. (2017). Using radio and interactive ICTs to improve food security among smallholder farmers in Sub-Saharan Africa. Telecommunications Policy, 41(7-8), 670-684. 
Creative Commons User License: CC BY-NC-ND

Abstracted by: EBSCOhost, Electronic Journals Service (EJS), Google Scholar, Journal Seek, Scientific Commons,

Food and Agricultural Organization (FAO), CABI and Scopus

http://eoi.citefactor.org/10.11226/v25i4
Journal of Agricultural Extension

Vol. 25 (4) October, 2021

ISSN(e): 24086851; ISSN(Print); 1119944X

http://journal.aesonnigeria.org

http://www.ajol.info/index.php/jae

Email: editorinchief@aesonnigeria.org

Kapuscinski, P. (2017). Agriculture ICT Extension Services; Improving smallholders' knowledge of agricultural practices and markets through innovative media platforms https://www.innovationpolicyplatform.org/www.innovationpolicyplatform.org/system/file s/4_Agri\%20ICT\%20Extension_Agri_Nov20/index.pdf.

Khan, N., Siddiqui, N. B., Khan, N., Ahmad, Z., Ismail, S., Javed, H. H., Ali, S., Kazim, R., Azam, T., \& Kasi, A. K. (2020). Mass Media Role in Agricultural and Rural Development. International Journal of Advanced Research in Biological Sciences, 7(4), 199-209.

Kumar, U., Werners, S., Roy, S., Ashraf, S., Hoang, L. P., Kumar Datta, D., \& Ludwig, F. (2020). Role of information in farmers' response to weather and water related stresses in the Lower Bengal Delta, Bangladesh. Sustainability, 12(16), 1-24.

Kurdyś-Kujawska, A., Strzelecka, A., \& Zawadzka, D. (2021). The Impact of Crop Diversification on the Economic Efficiency of Small Farms in Poland. Agriculture, 11(3), 1-21.

Maertens, A., Michelson, H., \& Nourani, V. (2020). How do farmers learn from extension services? evidence from malawi. American Journal of Agricultural Economics, 103(2), 569-595.

Mojaki, R. A., \& Keregero, K. J. B. (2019). Turning challenges into opportunity: Potential for adoption of e-extension in Lesotho. Journal of Agricultural Extension and Rural Development, 11(11), 184-191.

Muhammad, A. L. I., Man, N., Abd Latif, I., Muharam, F. M., \& Omar, S. Z. (2018). The use of information and communication technologies in agricultural risk management by the agricultural extension services in Malaysia. International Journal of Agriculture Environment and Food Sciences, 2(1), 29-35.

Naruka, P. S., Verma, S., Sarangdevot, S. S., Pachauri, C. P., Kerketta, S., \& Singh, J. P. A. (2017). Study on Role of WhatsApp in Agriculture Value Chains. Asian Journal of Agricultural Extension, Economics and Sociology, 20(1):1-11.

Okpukpara, B. (2016). Examining the control of bird flu risks among Nigerian poultry producers: implication for effectiveness of biosecurity knowledge, attitude, and practices (EBKAP). Agricultural and Food Economics, 4(1), 1-19.

Onubedo, G., Bodunrin, S., \& Ishaku, J. (2018). Project Report: Digital Technology and Fertilizer Reforms in Nigeria.

Phillip, D., \& Ndirpaya, Y. D. (2020). Digitalization in Agriculture, Food and Nutrition - A Case Study of Nigeria. FARA Research Report 5(10): Pp 66.

Rashid, S. M. M., \& Islam, M. R. (2016). Problems faced by farmers in application of eAgriculture in Bangladesh. Journal of Agricultural Economics and Rural Development, $3(1), 79-84$. 
Creative Commons User License: CC BY-NC-ND

Abstracted by: EBSCOhost, Electronic Journals Service (EJS), Google Scholar, Journal Seek, Scientific Commons,

Food and Agricultural Organization (FAO), CABI and Scopus

http://eoi.citefactor.org/10.11226/v25i4
Journal of Agricultural Extension

Vol. 25 (4) October, 2021

ISSN(e): 24086851; ISSN(Print); 1119944X

http://journal.aesonnigeria.org

http://www.ajol.info/index.php/jae

Email: editorinchief@aesonnigeria.org

Saiz-Rubio, V., \& Rovira-Más, F. (2020). From smart farming towards agriculture 5.0: A review on crop data management. Agronomy, 10(2), 1-21.

Savary, S., Akter, S., Almekinders, C., Harris, J., Korsten, L., Rötter, R., Waddington, S. \& Watson, D. (2020). Mapping disruption and resilience mechanisms in food systems. Food Security, 12(4), 695-717.

Senekela (2018). Market Intelligence Service for Farmers. 2018. Available online: https://www.nitidae.org/en/actions/senekela-service-de-collecte-des-prix-du-marchedestine-aux-agriculteurs (accessed on 30 May 2018).

Tata, J. S., \& McNamara, P. E. (2018). Impact of ICT on agricultural extension services delivery: evidence from the Catholic Relief Services SMART skills and Farmbook project in Kenya. The Journal of Agricultural Education and Extension, 24(1), 89-110.

Tinsley, E., \& Agapitova, N. (2018). Private Sector Solutions to Helping Smallholders Succeed: Social Enterprise Business Models in the Agriculture Sector. World Bank.

Thakur, D., \& Chander, M. (2018). Social media in agricultural extension: benefits and challenges under Indian context. Asian Journal of Agricultural Extension, Economics and Sociology, 27(2), 1-8.

UNESCO. (2016). Education for People and Planet: Creating Sustainable Futures for All. Global Education Monitoring Report 2016. Paris, UNESCO. unesdoc. unesco.org/images/0024/002457/245752e.pdf (Accessed 9 January 2018).

Yousaf, Z., Radulescu, M., Sinisi, C. I., Serbanescu, L., \& Păunescu, L. M. (2021). Towards sustainable digital innovation of SMEs from the developing countries in the context of the digital economy and frugal environment. Sustainability, 13(10), 1-28. 